\title{
Herring Investigations at Plymouth. II. The Average Number of Vertebrae for Herrings from the English Channel and South-East of Ireland.
}

\author{
By \\ E. Ford, A.R.C.Sc., \\ Naturalist at the Plymouth Laboratory.
}

With a Chart and 1 Figure in the Text.

\section{CONTENTS.}

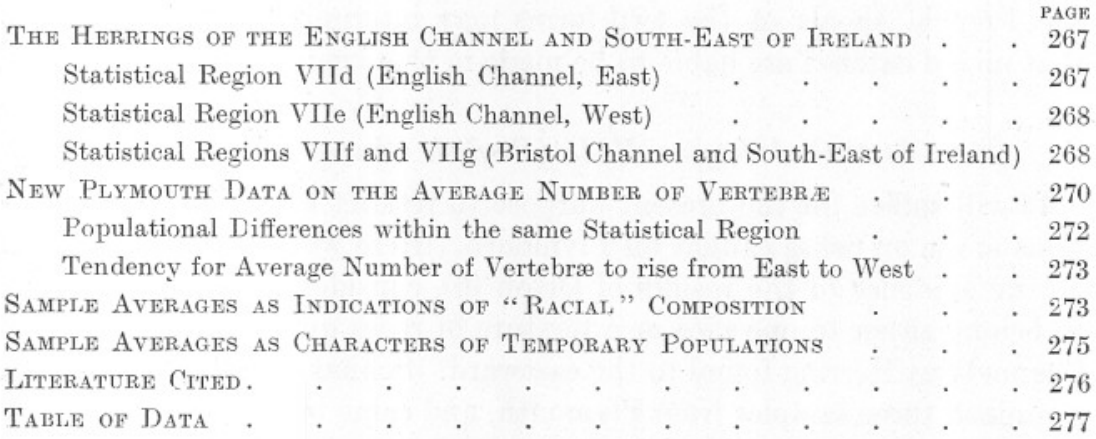

The Herrings of the English Channel and South-Fast OF IRELAND.

THE published observations of other workers, on samples of herrings taken from the area under consideration, whether they relate to the study of such morphological characters as the number of vertebræ and keeled scales, or are chiefly concerned with the examination of the growth of the fishes as indicated by their scales, demonstrate very clearly that the eastern, central and western sectors of the area are visited by herrings which differ in character. It will be convenient to summarise the opinions of these workers under the headings of the statistical regions in which the samples were taken. The reader is referred to the chart on page 269, which shows the geographical extent of the regions dealt with.

\section{Statistical Region VIId (English Channel, East).}

Johansen (4), Hodgson (2 and 3 ) and le Gall (5) have made interesting contributions to our knowledge of fishes caught in this region. On the one hand we have Johansen who, on the evidence of samples examined 
by Sauvage and Canu, Cligny, Delsman and Redeke, postulates the existence of a race of herrings which he calls "Channel Sea Herring" to include the winter-spawning fish of both the eastern end of the English Channel and of the south-western corner of the North Sea. On the other hand, both Hodgson and le Gall, from their studies of scales, oppose this view, and draw distinction between the herrings of the Southern Bight ("Southern North Sea Type" of Hodgson) and those of the Channel proper. They admit that shoals of the Southern North Sea Type enter the Channel to spawn, but contend that after spawning they return to the North Sea. In contrast with this, they hold that the fish of the Channel proper are essentially Channel fish, quite distinct from the Southern North Sea Type, which carry out the whole of their migratory cycle within the confines of the Channel itself. On a line running approximately from Newhaven on the English side to Cap d'Antifer on the French, shoals of the two forms may intermingle, with the result that mixed catches are liable to be made in this vicinity.

\section{Statistical Region VIIe (English Channel, West).}

It will suffice for the present purpose to restrict attention to observations made on fishes caught off Plymouth. Here we find that Johansen, on the evidence of the results of Orton (6), considers the Plymouth fish to belong either to one race or a mixture of races quite distinct from his Channel Sea Herring found to the eastward. Schnakenbeck (8), however, examined three samples from Plymouth, and came to the conclusion that two of the samples could be considered representative of such a new race, but that the third appeared similar to Johansen's Channel Sea Herring. Le Gall's view is that the Plymouth fish belong to what he terms " Hareng type Atlantique, variété côtière." He believes that all along the English and French coasts of the English Channel, westwards of a line from Newhaven to Cap d'Antifer, the herrings belong to one coastal type of herring which carry out the whole of their migratory cycle within the English Channel. Watkin (10) has also examined fishes from Plymouth and compared them with those from still more westerly waters, and he tends to the view that there is a general relationship between them.

\section{Statistical Regions VIIf and VIIg (Bristol Channel and South-East of Ireland).}

The published work on herrings from these two regions is limited in extent. The work of Heldt (1) was, until recently, the chief evidence used as reference by others. Heldt regarded the "Smalls" trawled herrings as forming yet another distinct race, and his finding is quoted and accepted by Johansen and Schnakenbeck. In the 


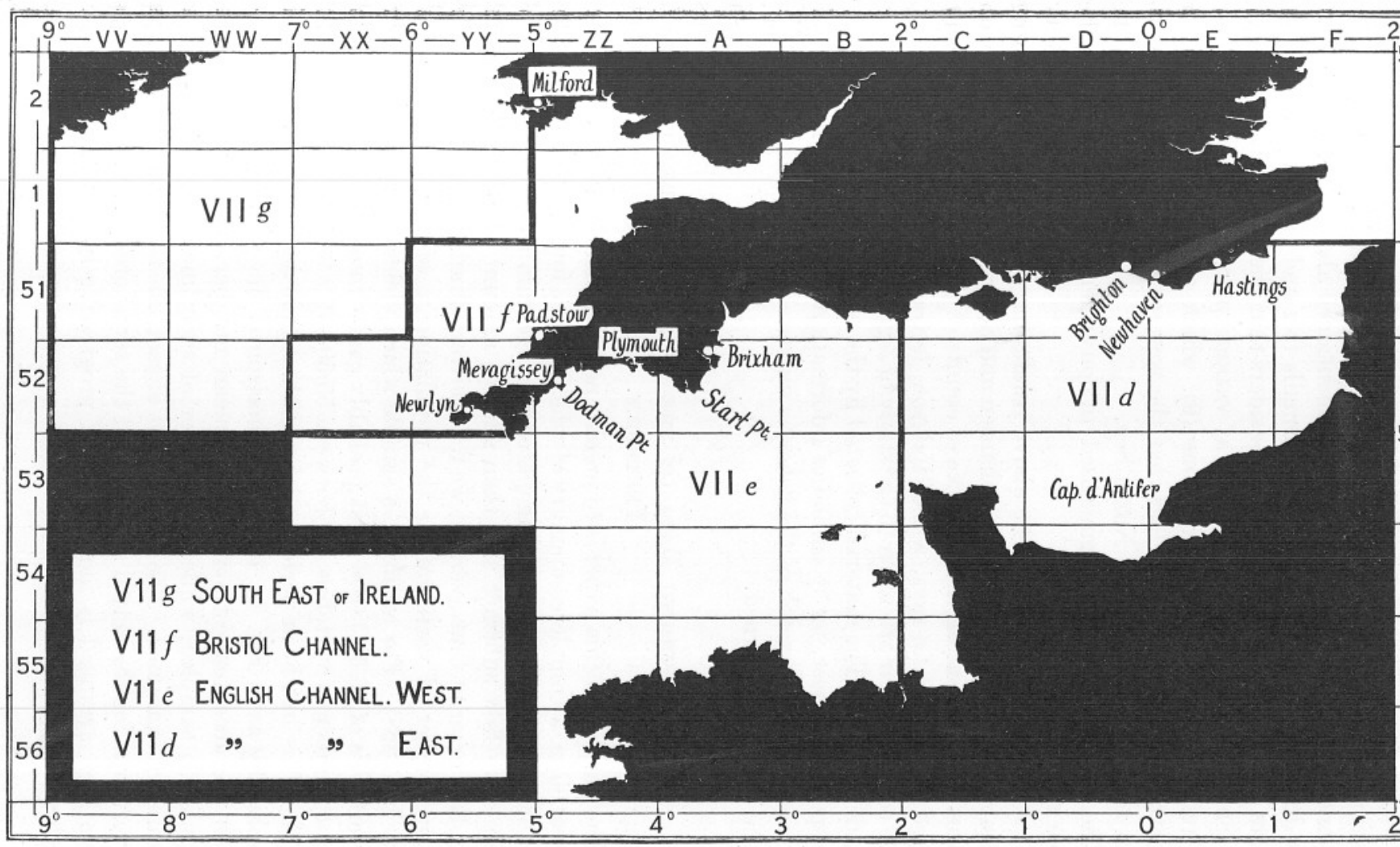

Chart showing Statistical Regions dealt with in this Paper. 
case of le Gall, we find that he proffers the name of " race Atlantique variété du large," thereby suggesting some difference from and yet some relationship between the Smalls fish and his "variété côtière" from the Channel. Watkin, as has already been mentioned above, does not favour any distinction of race between the Smalls fish and those taken off the coasts of Devon and Cornwall, but considers that the former after leaving the Smalls grounds come to spawn at various places in the latter area. He refers to Storrow's observations (9), which are broadly similar in import, and emphasizes the fact that the western fishes are much larger than those of the Southern North Sea.

The foregoing may be summarised in convenient tabular form. (See table on opposite page.)

It is to be observed that the above results have been reached by two distinct methods of approach. Johansen and Schnakenbeck have arrived at their conclusions on the evidence of counts of the number of vertebræ, keeled scales and fin-rays, while Hodgson, le Gall, Watkin and Storrow have confined their attention to the study of " growth facies " by measurements of scales. The material collected by the present writer is, therefore, of especial interest, for it embodies information on both the number of vertebræ and the growth of the fishes as indicated by their scales, in each of the regions concerned.

\section{New Plymouth Data on the Average Number of VERTEBRA.}

The purpose of this paper is to present new data on the average number of vertebræ, a complete summary of which will be found in Table $I$ at the end of this paper. If to the calculated average number of vertebræ for a sample we first subtract and then add an amount equal to twice the standard error of that average, we fix arbitrary limits between which the mean number of vertebræ for the population most probably lies (vide Part I, p. 258). For example, a sample which yields an average number of vertebræ of $55 \cdot 50 \pm 0 \cdot 06$ most probably came from a population whose mean number of vertebræ lay between $55 \cdot 50-(2 \times 0 \cdot 06)$ and $55 \cdot 50+(2 \times$ $0 \cdot 06$ ). This has been performed for each sample and the results plotted graphically as in Fig. 1; each short horizontal line in the diagram indicates the accepted estimate of the mean number of vertebræ for the population sampled, while the number of such lines shows the number of samples examined. The centre point of each line is the average number of vertebræ for the actual sample, and the serial order in which the lines have been arranged is merely one of progressive increase in the value of these sample means. 


\section{Statistical Regions.}

\begin{tabular}{|c|c|c|c|}
\hline Investigator. & VIId. & VIIe. & VIIg. \\
\hline Johansen & 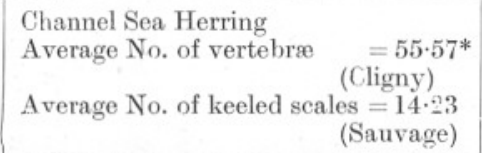 & 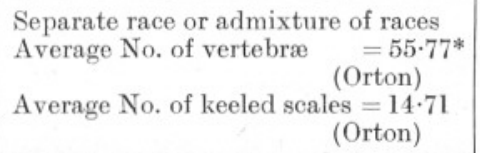 & $\begin{array}{l}\text { Separate race } \\
\text { Average No. of vert. }=56 \cdot 49^{*} \\
\text { (le Danois and Heldt) }\end{array}$ \\
\hline Schnakenbeck & & $\begin{array}{l}\text { (a) Separate race } \\
\text { Average No. of vertebra }=55 \cdot 85^{*} \\
\text { Average No. of keeled scales }=14 \cdot 37 \\
\text { (b) Channel Sea Herring (Johansen) } \\
\text { Average No. of vertebræ }=55 \cdot 64^{*} \\
\text { Average No. of keeled scales }=13 \cdot 85\end{array}$ & \\
\hline Hodgson & 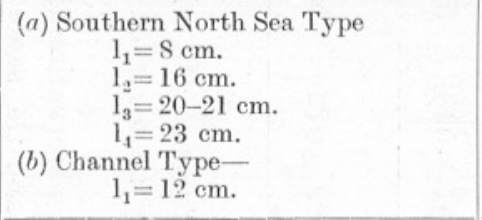 & & \\
\hline le Gall & $\begin{array}{l}\text { (a) Southern North Sea Type } \\
\text { (Hodgson) } \\
\text { (b) Race Atlantique } \\
\text { variété côtière }\end{array}$ & $\begin{array}{l}\text { Race Atlantique } \\
\text { variété côtière }\end{array}$ & $\begin{array}{l}\text { Race Atlantique } \\
\text { variété du large }\end{array}$ \\
\hline Watkin & & Fishes related ir & these regions. \\
\hline
\end{tabular}

* It should be noted that the average is here expressed according to the Plymouth method of recording, and not necessarily as given in the original work (vide Part I, p. 253)。 
Populational Differences within the same Statistical Region.

In the first place it will be seen that in each of the statistical regions there is a large range of variation in the average number of vertebræ. Comparisons between pairs of estimates show that the differences may be large enough to suggest that more than one type of population had been sampled. This may be exemplified by giving the values of the highest estimate and the lowest for each region together with the results of the liests of significance applied to the difference between them :-

\begin{tabular}{|c|c|c|c|c|}
\hline Statistical Region. & $\begin{array}{r}\text { Highest estimate } \\
\mathrm{M}_{\mathrm{h}} \cdot\end{array}$ & $\begin{array}{r}\text { Lowest estimate } \\
\mathrm{M}_{\mathrm{l}} \cdot\end{array}$ & $\begin{array}{c}\text { Difference } \\
\left(\mathrm{M}_{\mathrm{h}}-\mathrm{M}_{\mathrm{L}}\right) \cdot\end{array}$ & $\begin{array}{c}\text { Standard } \\
\text { error of } \\
\text { difference }\end{array}$ \\
\cline { 1 - 4 } VIId & $55 \cdot 86 \pm \cdot 071$ & $55 \cdot 62 \pm \cdot 066$ & $0 \cdot 24$ & $0 \cdot 090$ \\
\hline $\begin{array}{c}\text { VIIe } \\
\text { Plymouth area } \\
\text { only }\end{array}$ & $55 \cdot 91 \pm \cdot 061$ & $55 \cdot 57 \pm \cdot 056$ & $0 \cdot 34$ & $0 \cdot 083$ \\
\hline $\begin{array}{c}\text { VIIh } \\
\text { Padstow }\end{array}$ & $55 \cdot 882 \pm \cdot 056$ & $55 \cdot 645 \pm \cdot 067$ & $0 \cdot 24$ & $0 \cdot 087$ \\
\hline $\begin{array}{c}\text { VIIg } \\
\text { Smalls trawled }\end{array}$ & $55 \cdot 97 \pm \cdot 048$ & $55 \cdot 63 \pm \cdot 078$ & $0 \cdot 34$ & $0 \cdot 091$ \\
\hline $\begin{array}{c}\text { VIIg } \\
\text { Drift fishery }\end{array}$ & $55 \cdot 99 \pm \cdot 072$ & $55 \cdot 48 \pm \cdot 053$ & $0 \cdot 51$ & $0 \cdot 090$ \\
\hline
\end{tabular}

In each case the difference $\left(M_{h}-M_{1}\right)$ easily exceeds twice its own standard error, and may be regarded as indicative of real populational difference.

The importance of the observation that undoubted populational differences occur within one and the same statistical region cannot be overemphasized. The suggestion given in Part I (p. 265) that it is unsafe to draw conclusions as to the herring populations frequenting an area unless sampling has been frequent and continuous, is amply demonstrated by the above results. In each and every statistical region the results raise big difficulties regarding the various " races" postulated from an earlier study of a few samples. For instance, in region VIIg, instead of having to account for a single high value of 56.49 (Race Atlantique variété du large), we have to deal with a whole series of sample averages down to as low as $55 \cdot 48$. 


\section{Tendency for Average Number of Vertebra to rise from East to West.}

Now although there is a large range of variation in the average number of vertebræ among samples taken within the same statistical region, the data shown in Fig. 1 also suggest that there is a general tendency for the average number of vertebræ to rise from east to west. The average of the individual sample averages for the same region may be used to demonstrate this tendency :-

\begin{tabular}{|l|c|c|c|c|c|}
\hline & \multicolumn{5}{|c|}{ Statistical Region. } \\
& $\begin{array}{c}\text { VIId } \\
\text { (Sussex). }\end{array}$ & $\begin{array}{c}\text { VIIe } \\
\text { (Brixham). }\end{array}$ & $\begin{array}{c}\text { VIIe } \\
\text { (Plymouth). }\end{array}$ & $\begin{array}{c}\text { VIIf } \\
\text { (Padstow). }\end{array}$ & VIIg. \\
\hline $\begin{array}{l}\text { Average of } \\
\text { Sample averages }\end{array}$ & $55 \cdot 70$ & $55 \cdot 74$ & $55 \cdot 78$ & $55 \cdot 75$ & $55 \cdot 84$ \\
\hline
\end{tabular}

This second observation, unlike the first, is in general agreement with the earlier results. Thus Johansen's "Channel Sea Herring" to the eastward have the low average of 55.57 vertebræ; the Plymouth averages (Orton, 55·77, and Schnakenbeck, 55.64 and 55·85) occupy an intermediate position, while to the westward Heldt's fishes from the Smalls have the high average of $56 \cdot 49$ vertebræ.

Schnakenbeck (8), using Johansen's data, has shown that the average number of vertebræ is low in areas of low salinity and high in areas of high salinity. It is of interest, therefore, to note that the general tendency for the average to rise from east to west in the English Channel is a repetition of Schnackenbeck's observation. Schmidt (') has shown, also, that populations of Zoarces viviparus have a lower number of vertebræ in the inner parts of the fiords than in the outer parts, and that the salinity shows a gradation which corresponds strikingly with the gradation in the average number of vertebræ. As Schmidt points out, however, we are not justified in interpreting the upward trend of the average number of vertebræ as the direct effect of the upward change in salinity, but we are entitled to regard the coincidence of the two phenomena as an expression of the importance of environment.

\section{Sample Averages as Indications of "Racial" Composition.}

If we presuppose that distinct " races" of herrings do actually exist, and accept the average number of vertebræ for a random sample as an indication of the "racial " composition of the stock sampled, we meet with the greatest difficulty in arriving at a satisfactory interpretation of the above sample data. In the first place, unless we are prepared to work 
on the hypothesis that the average number of vertebræ is independent of environment, we must take into account the age-composition of the sample. An annual variation in environment may induce an annual alteration in the average number of vertebræ, within the same race, so that the average for a random sample composed of fishes of several year-classes, is liable to variation from this cause. But the considerable variation in sample averages in the same statistical

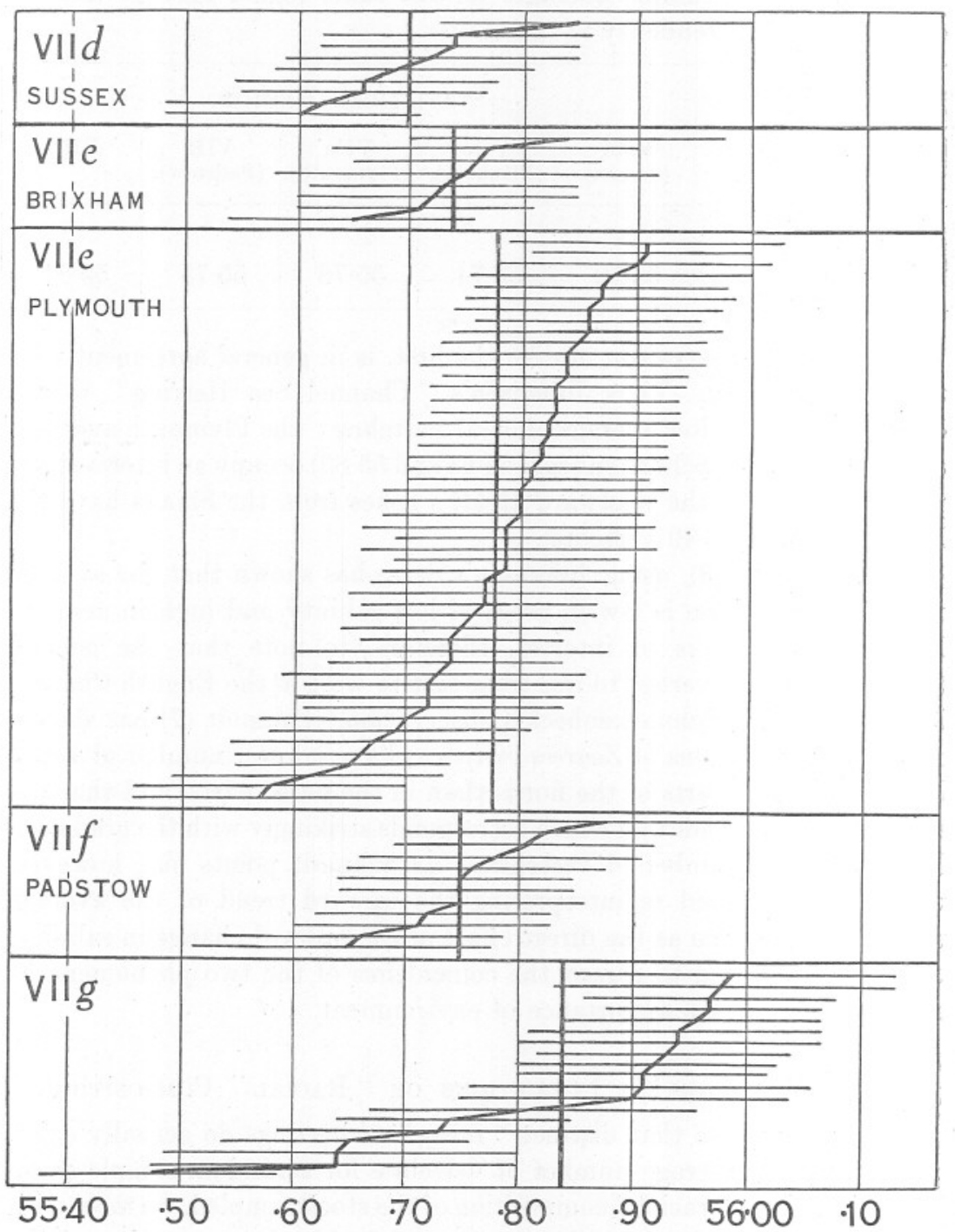

FIG. 1.-Number of vertebræ from samples taken in south and south-western waters For explanation see text, p. 270 . 
region cannot, under the "racial" hypothesis, be regarded as entirely due to the annual variations in environment just mentioned, so that, in the second place, we must admit that more than one race may occur within the same statistical region. Indeed, at times, it is necessary to assume an admixture of races at one and the same time. Moreover, neighbouring regions exhibit equally pronounced mixture. It is easily seen that the sorting out of our fishes into "races "is, under these circumstances, at best, highly speculative.

As stated in Part I (p. 264), therefore, it has been considered advisable, in the first instance, not to study the average number of vertebræ as an indication of "racial " composition, but to use it, as we use the other sample data, strictly as a character of a population of herrings frequenting a given region at the time of sampling.

\section{Sample Averages as Characters of Temporary Populations.}

If the fishes of a particular year-class in a sample A were found to agree with those of a similar age in a second sample $\mathrm{B}$ in the average of vertebræ, it would be logical to argue that the fishes of the two samples had, in their early larval life, developed their vertebræ under identical influences. If, also, they agreed in their growth characters as indicated by scale measurements, then it would be reasonable to suspect that from their earliest days until the time of sampling, the fishes of the two samples had lived and grown under similar conditions.

The above paragraph illustrates the general principle upon which it is proposed to consider sample data. That is to say, the average number of vertebræ will be used as an index of the conditions under which the vertebræ were actually developed, while the growth data derived from measurements of scales will be utilised as an index of the conditions prevailing after the vertebræ number was definitely established. Used in conjunction, the two sets of data should enable the investigator eventually to discover the system of movements of shoals by which the different herring populations (as indicated by his samples) observed in his region were brought about.

It will be apparent to the reader that if herring "races" do exist, the knowledge of the local movements of herrings acquired by the method suggested would reveal the particular "races" represented. But the advantage of the method lies in the fact that in the initial study of the movements, work may proceed without any thought of "races" or "racial" composition.

Further study of the actual data on average number of vertebræ must thus be deferred until an account has been given of the sample data on age and growth for fishes in the statistical regions dealt with. 


\section{LITERATURE CITED.}

1. Le Danois, E., and Heldt, H. "Les Harengs des Smalls et les Conditions hydrologiques de leur Migrations." Office Scient. Tech. des Pêches Mar., Notes et Mem., No. 36, 1924.

2. Hodgson, W. C. "Investigations into the Age, Length and Maturity of the Herring of the Southern North Sea." Part II. Min. Agric. Fish., Fish. Invest., Ser. II, Vol. VIII, No. 5, 1925.

3. Hodgson, W. C. " The Herrings of the Eastern Part of the English Channel." Nature, March 6th, 1926.

4. Johansen, A. C. " On the Summer and Autumn Spawning Herrings of the North Sea." Medd. fra. Komm. Havunders., Ser. Fisk. VII, Nr. 5, 1924.

5. Le GaLL, J. "Études diverses sur la question du Hareng." Office Scient. Tech. des Pêches Mar., Notes et Rapp., No. 48, 1926.

6. ORton, J. H. " An Account of the Researches on Races of Herrings Carried out by the Marine Biological Association at Plymouth, 1914-15." Journ. Mar. Biol. Assoc., Vol. XI, No. 1, 1916.

7. Sснмidt, J. "Racial Investigations. I. Zoarces viviparus $L$. and local races of same." C. R. Lab. Carlsberg, Vol. 13, 1916.

8. Schnakenbeck, W. "Rassenuntersuchungen am Hering." Berichte Deutsch. Wiss. Komm. Meeresforsch. Neue Folge, Bd. III, Heft 2, II, 1927.

9. Storkow, B. "Herring Investigations." Dove Mar. Lab. Rept., N.S. XIII, for the year ending June 30th, 1924.

10. W Rept. Mar. and Fr. Water Invest., Dept. Zool., Univ. Coll., Wales, Aberystwyth, Vol. II, 1927. 
TABle I.

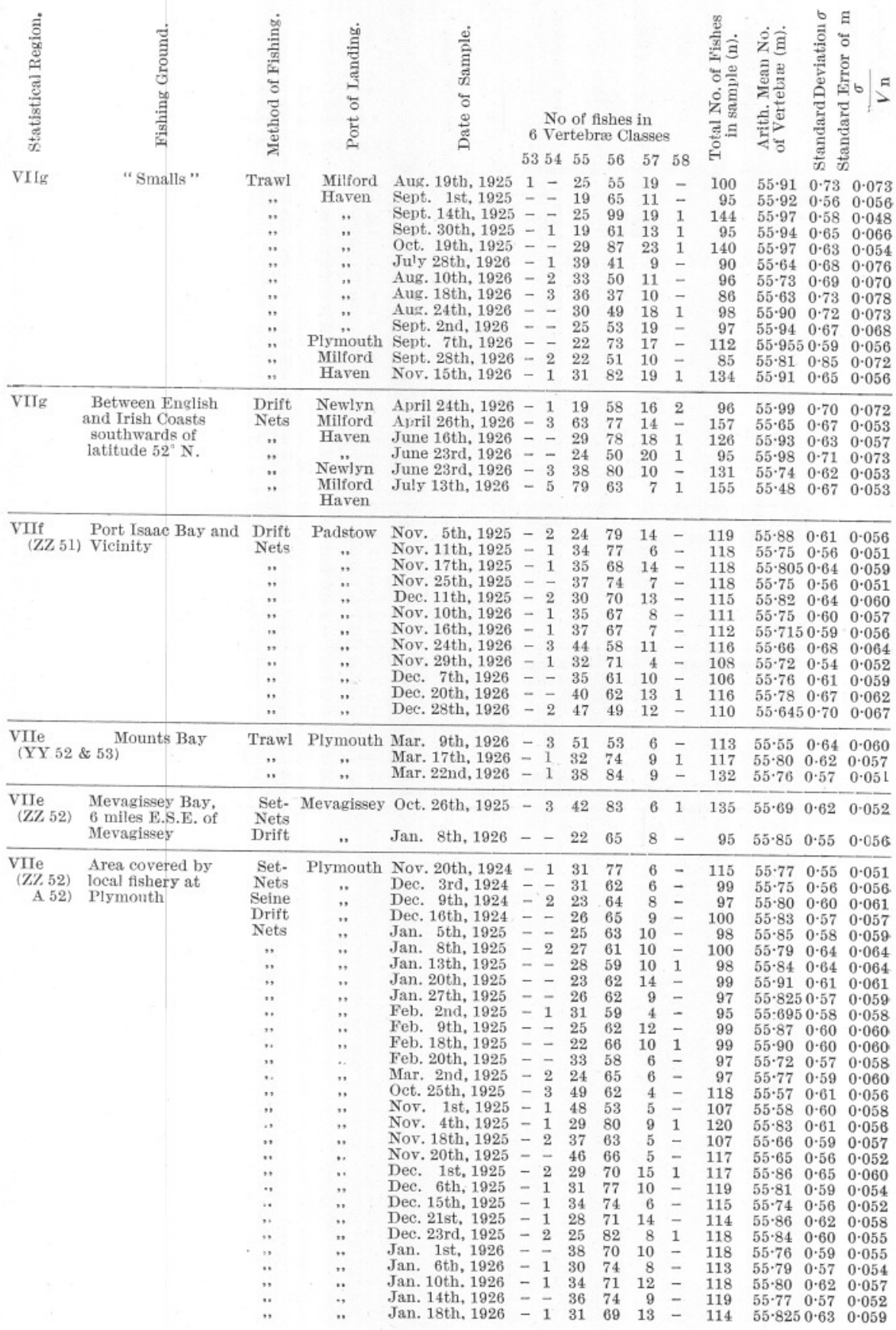




\section{TABLE I-continued.}

$$
\text { 递 }
$$$$
\text { 壱 }
$$

VIIe Area covered by (Z7. 52 local flshery at A. 52) Plymouth

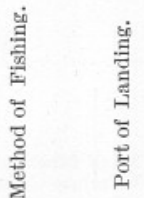

$$
\text { 窟 }
$$

No of fishes in

6 Vertebræ Classes.

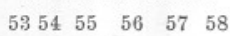

Plymouth Jan. 25th, 1926 - 2 2 $25 \quad 81 \quad 7 \quad \begin{array}{llll}1 & \end{array}$ Jan. 28th, 1926 - $2 \quad 28 \quad 74 \quad 11 \quad-$

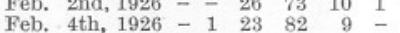

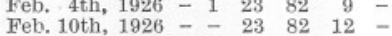
June 8th, 1926 - $\begin{array}{lllll}3 & 27 & 53 & 9 & -\end{array}$ Oct. 18th, 1926 - - $5051 \quad 8$ Oct. 21st, $1926-\overline{-} \quad 32 \quad 71 \quad 9-1$ Nov. 3rd, 1926 - -33778 Nov. 4th, 1926 - -307210 Nov. 15th, 1926 - $2 \quad 28 \quad 64 \quad 11 \quad-$

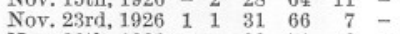
Nov. 30th, 1926 - -39718 Dec. 6th, 1926 - 2 2 $28 \quad 70 \quad 14 \quad-$

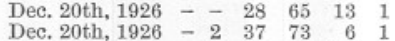
Dec. 30th, 1926 - $\begin{array}{lllll}3 & 42 & 62 & 12 & -\end{array}$

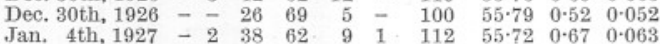

\begin{tabular}{|c|c|c|c|c|c|c|c|c|c|c|c|c|c|}
\hline $\begin{array}{l}\text { VIIe } \\
\text { (A 52) }\end{array}$ & $\begin{array}{l}\text { River Dart } \\
\text { Great West Bay }\end{array}$ & $\begin{array}{l}\text { Seine } \\
\text { Set } \\
\text { Nets } \\
\text { and } \\
\text { Drift } \\
. " \\
\ddot{y}\end{array}$ & $\begin{array}{l}\text { Brixham } \\
\text { ", } \\
\ddot{"} \\
\ddot{"} \\
\ddot{"}\end{array}$ & $\begin{array}{l}\text { Dec. } 10 \mathrm{th}, 1925 \\
\text { Nov. } 10 \mathrm{th}, 1925 \\
\text { Nov. } 26 \mathrm{th}, 1925 \\
\text { Dec. } 16 \mathrm{th}, 1925 \\
\text { Jan. } 4 \mathrm{th}, 1926 \\
\text { Oct. } 27 \mathrm{th}, 1926 \\
\text { Nov. } 23 \mathrm{rd}, 1926 \\
\text { Dec. } 14 \mathrm{th}, 1926\end{array}$ & $\begin{array}{l}-1 \\
=1 \\
=3 \\
-1 \\
=\frac{2}{-} \\
=\frac{2}{5}\end{array}$ & $\begin{array}{l}32 \\
17 \\
37 \\
28 \\
24 \\
28 \\
40 \\
44\end{array}$ & $\begin{array}{l}53 \\
51 \\
65 \\
58 \\
32 \\
71 \\
70 \\
67\end{array}$ & $\begin{array}{r}11 \\
7 \\
11 \\
5 \\
8 \\
6 \\
6 \\
6\end{array}$ & $\begin{array}{l}- \\
- \\
- \\
- \\
- \\
-\end{array}$ & $\begin{array}{r}97 \\
76 \\
116 \\
92 \\
94 \\
64 \\
107 \\
116 \\
119\end{array}$ & & $\begin{array}{l}0.66 \\
0.59 \\
0.67 \\
0.58 \\
0.66 \\
0.58 \\
0.56 \\
0.61\end{array}$ & $\begin{array}{l}0 \cdot 068 \\
0 \cdot 068 \\
0.062 \\
0 \cdot 060 \\
0 \cdot 083 \\
0.056 \\
0 \cdot 052 \\
0.055\end{array}$ \\
\hline $\begin{array}{l}\text { VIId } \\
\text { (D 51 } \\
\text { E 51) }\end{array}$ & & $\begin{array}{c}\text { Set } \\
\text { Nets or } \\
\text { Drift } \\
\text { ". } \\
\text { ". } \\
\text { " } \\
\text { ", }\end{array}$ & $\begin{array}{c}\text { Plymouth } \\
\text { Brighton } \\
, " \\
\ddot{"} \\
\text { Hastings } \\
\text { Brighton }\end{array}$ & $\begin{array}{l}\text { Dec. } 9 \text { th, } 1924 \\
\text { Oct. 19th. } 1925 \\
\text { Nov. 10th, } 1925 \\
\text { Dec. 1st, } 1925 \\
\text { Nov. 1st, } 1926 \\
\text { Nov. 5th, } 1926 \\
\text { Dec. 2nd, } 1926 \\
\text { Dec. 10th, } 1926 \\
\text { June 29th, } 1927\end{array}$ & 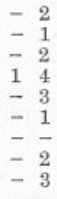 & $\begin{array}{l}26 \\
46 \\
30 \\
44 \\
42 \\
30 \\
36 \\
37 \\
37\end{array}$ & $\begin{array}{l}67 \\
58 \\
62 \\
66 \\
59 \\
58 \\
65 \\
56\end{array}$ & $\begin{array}{r}16 \\
10 \\
7 \\
6 \\
8 \\
7 \\
3 \\
31 \\
11\end{array}$ & $\begin{array}{l}\overline{-} \\
\overline{1} \\
\overline{-} \\
\bar{z} \\
\overline{-}\end{array}$ & $\begin{array}{r}98 \\
124 \\
97 \\
118 \\
119 \\
97 \\
97 \\
115 \\
99\end{array}$ & & $\begin{array}{l}0.70 \\
0.63 \\
0.65 \\
0.72 \\
0.64 \\
0.60 \\
0.54 \\
0.65 \\
0.56\end{array}$ & $\begin{array}{l}0.071 \\
0 \cdot 056 \\
0 \cdot 066 \\
0.066 \\
0.059 \\
0.061 \\
0.054 \\
0.061 \\
0.056\end{array}$ \\
\hline
\end{tabular}

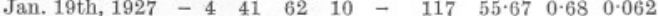

